\title{
EROS PEDE PASSAGEM: O (NÃO) LUGAR DO AMOR E DO AFETO NAS NARRATIVAS JURÍDICAS CONTEMPORÂNEAS
}

\author{
"EROS" ASKS FOR PASSAGE: THE (NO) PLACE OF LOVE AND AFFECTION IN \\ CONTEMPORARY LEGAL NARRATIVES
}

\author{
Doglas Cesar Lucas ${ }^{1}$ \\ André Leonardo Copetti Santos ${ }^{2}$
}

\section{RESUMO}

Este artigo pretende compreender conceitual e filosoficamente o amor e as formas a partir das quais ele delineou as relações familiares e suas narrativas. Percebe-se, inicialmente, que as famílias tradicionais se organizavam em torno da figura paterna e exclusivamente mediante o casamento, de modo que os laços amorosos entre seus membros não pareciam ter a mesma importância que têm hoje para a unidade familiar. Atualmente as relações familiares estão menos sólidas, menos arraigadas, mais complacentes, democráticas, igualitárias e plurais, baseadas no amor e nos laços de afetividade entre seus membros. Em decorrência de tais transformações, novos saberes e práticas passaram a constituir o campo de estudo das ciências sociais e humanas, interessando para o presente trabalho notadamente o direito. Para enfrentamento dos temas aqui debatidos, valeu-se da revisão bibliográfica.

Palavras-chave: Amor; Direito; Família; Modernidade; Afeto.

\begin{abstract}
This article aims to understand conceptually and philosophically the love and the ways in which he outlined family relationships and their narratives. It is noticed, initially, that traditional families were organized around the father figure and exclusively through marriage, so that the loving bonds between their members did not seem to have the same importance that they have today for the family unit. Currently, family relationships are less solid, less entrenched, more complacent, democratic, egalitarian and plural, based on love and the bonds of affection among

\footnotetext{
${ }^{1}$ Doutor em Direito pela UNISINOS e Pós-Doutor em Direito pela Università Degli Studi di Roma Tre. Professor dos Cursos de Graduação, Mestrado e Doutorado em Direito da Universidade Regional do Noroeste do Estado do Rio Grande do Sul - UNIJUÍ e do Curso de Graduação em Direito da Faculdade CNEC Santo Ângelo. Professor Colaborador dos Cursos de Mestrado e Doutorado em Direito da URI, Santo Ângelo. Editor-chefe da Revista Direito em Debate (B1). Avaliador Inep/Mec. Afiliação: Universidade Regional do Noroeste do Estado do Rio Grande do Sul- UNIJUI ORCID: https://orcid.org/0000-0003-3703-3052. Lattes: http://lattes.cnpq.br/1332521470619712. E-mail: doglasl@unijui.edu.br

${ }^{2}$ Pós-Doutor pela Universidade do Vale do Rio dos Sinos (UNISINOS, 2014) e pós-doutorando pela Universidade de Santiago do Chile (USACH). Possui mestrado (1999) e Doutorado (2004) em Direito pela Universidade do Vale do Rio dos Sinos e graduação em Direito pela Universidade de Cruz Alta (1988). Atualmente é professor do corpo permanente do Programa de Pós-Graduação em Direito da URI, Santo Ângelo, RS e do Programa de PósGraduação em Direito da UNIJUÍ, Ijuí, RS. Coordenador Executivo do PPGD/URISAN. Afiliação: Universidade Regional do Noroeste do Estado do Rio Grande do Sul- UNIJUI e Universidade Regional Integrada do Alto Uruguai e das Missões - URI ORCID: https://orcid.org/0000-0003-1087-1195 Lattes: http://lattes.cnpq.br/5126982210763673 . E-mail: andre.co.petti@ hotmail.com
} 
its members. As a result of such transformations, new knowledge and practices started to constitute the field of study of social and human sciences, interesting for the present work, notably the law. In order to face the topics discussed here, a bibliographic review was used.

Keywords: Love; Law; Family; Modernity; Affection.

\section{INTRODUÇÃO}

Amor como louvor religioso, amor cortês, amor paixão, amor romântico, amor caridoso. Seja como for, o fato é que o amor e suas diferentes formas de (se) comunicar e de ser narrado, de constituir e de ser constituído, acompanham a aventura de viver desde a mais inicial experiência que se tem da humanidade. E mais do que em qualquer outro tempo, o amor, contemporaneamente, parece ter se transformado em algo a ser buscado a todo custo, uma condição para a felicidade, um elemento indispensável para se viver uma vida boa. Nem mesmo a liberação sexual, que permitiu novos arranjos envolvendo o desejo, foi capaz de libertar o amor e ressignificá-lo para além das institucionalidades que ainda o percebem como um vetor de perenidade, segurança e estabilidade.

Sucesso financeiro, grande saber intelectual, notoriedade e reconhecimento sociais são, sem dúvida, aspectos importantes da vida. Mas parece que é somente no amor que a experiência de existir e estar na vida acontece de modo pleno (MAY, 2012). É como se as noções de autorrealização e individualização projetaram em nossas experiências sexuais e amorosas/afetivas um fator de reconhecimento tanto ou mais importante do que fazemos em relação às nossas possibilidades financeiras ou intelectuais, por exemplo. Isso significa que o amor e o afeto possibilitam o reconhecimento ou a sensação de perda de valor próprio dependendo das capacidades sexuais de cada sujeito (ILLOUZ, 2016).

O objetivo central do presente artigo é demostrar como o aparecimento das novas narrativas amorosas ressignificaram as estruturas familiares ao longo da história e transformaram o amor numa aventura a dois que cada vez menos interessa à comunidade, esgotando-se nas regras definidas pelos amantes, para quem o direito quase nada pode dizer. Nesse sentido, o primeiro momento do texto constitui-se numa tentativa de escavar e entender historicamente os elementos que permitiram, desde os primórdios da tradição judaica, fundar instituições baseadas nas diferentes formas de amar. Na parte final do texto, é reforçada a hipótese segundo a qual os novos arranjos amorosos são fundados na liberdade e na 
autenticidade permitidas aos amantes que nenhuma regra jurídica poderá entabular. Ao não regular o amor que o direito lhe garante a sua maior potência, concluímos. O artigo foi construído a partir de uma revisão bibliográfica interdisciplinar.

\section{AMOR E AFETO NA NARRATIVA FAMILIAR}

A discussão sobre o afeto não é, de forma alguma, um tema novo na academia, mas ganhou certo protagonismo com a modernidade e suas tendências individualistas. $\mathrm{O}$ amor, como afeto básico, como desejo ou como um vínculo, sempre foi colocado em questão na definição das relações familiares e conjugais, tanto que se podem vislumbrar inúmeros relatos e "teorizações" desde as literaturas antigas até às pós-modernas. Embora tenha modificado suas representações e institucionalidades ao longo do tempo, o amor continua perpassando e dando condições às experiências humanas. Irrompem da ideia de amor narrativas biológicas e biográficas de diferentes matizes. $\mathrm{O}$ amor nunca vem solto. Tem suas formas próprias de comunicar e ser comunicado. Tem linguagem e dá sentido real e simbólico a um conjunto de instituições que depositam no amor a sua legitimidade. Ele opera forte na definição da paixão, da família, do casamento, da amizade, da solidariedade e, ainda hoje (e por que não sobretudo hoje?), da sexualidade. Seu estatuto mudou muito de programação ao longo da história, mas é praticamente impossível enfrentar a história das relações interpessoais olvidando o trato dado às relações afetivas e amorosas na definição das racionalidades e normalidades de cada época.

Para May (2012) a história do amor é marcada por quatro grandes transformações que produziram o seu itinerário conceitual na sociedade ocidental. A primeira transformação, situada, segundo o autor, entre Deuteronômio e Agostinho, refere-se ao valor do amor, transformado em uma espécie de virtude suprema. As escrituras hebraicas ordenam que Deus seja amado com toda a força, pois Deus é o amor e este amor é a fonte de toda a virtude verdadeira. $\mathrm{O}$ amor ao próximo também é ordenado pela lei divina. $\mathrm{O}$ amor assim percebido tem uma força ética, funciona como obrigação moral ao determinar que se deva amar a todos, inclusive o inimigo, o estrangeiro, o desconhecido. Por conta de uma segunda transformação, entre os séculos IV e XVI, foi atribuído ao homem um poder, literalmente divino, de amar. O homem torna-se divino pela capacidade de amar, apesar de o amor ao semelhante decorrer do amor a Deus. Uma terceira fase histórica, prossegue May (2012), iniciada no século XI e que atingiu seu ápice no século XVIII, humaniza o amor, depositando na experiência humana, antes reservada a Deus, a possibilidade de amar e de ser amado. Os limites entre o divino e o 
mundano, entre o natural e o sobrenatural, começam a se estreitar. Por fim, a quarta transformação na história do amor, que teve seu começo no século XVIII e que segundo o autor ainda está em curso, diz respeito ao amante, que se torna sujeito, um eu que se encontra, que se torna autêntico. $\mathrm{O}$ amor ganha seu estatuto, seu lugar próprio e torna-se projeto por todos desejado. Nos caminhos do amor há certa continuidade do sagrado, uma potência de estabilidade, de conforto, de projeto e, especialmente, de satisfação. Eis que o amor se fez Deus e fundou sua própria religião.

O amor foi o tema central da obra "O banquete", do filósofo grego Platão (428-347 a.C). Nesse diálogo, Fédro, Pausâneas, Erixímaco, Aristófanes, Agatão, Alcebíades e Sócrates, reunidos na casa de um deles para comemorar o sucesso de Agatão num concurso de tragédias, escolheram o amor como tema de conversação. Não falaram de seus amores particulares, mas do amor em geral. Dois discursos se destacam: o do poeta Aristófanes e o de Sócrates. Num primeiro momento o poeta retrata um mito, uma história que se desenvolveu num tempo primordial. Nesta época inaugural os homens e mulheres teriam sito duplos. Tinham quatro braços, quatro pernas, dois rostos, dois sexos, e tudo o mais nessa mesma proporção. Os homens eram homens porque tinham dois sexos de homem. As mulheres eram aquelas que tinham dois sexos de mulher. Os andrógenos (que em grego é literalmente homem-mulher; sexo composto) tinham o sexo de homem e o sexo de mulher. Ocorre que esses humanos tinham uma força e uma audácia exagerada, a ponto de decidirem escalar o céu e enfrentar as divindades. Os deuses não gostaram dessa empreitada e foram falar com Zeus, o qual, após ponderar entre diferentes soluções, resolveu cindir os humanos em dois e fazê-los mais fracos e mais úteis. Isso explicaria porque temos dois braços, duas pernas, mas também sugere que fomos amputados e mutilados. Os humanos teriam perdido a sua completude e com isso ficaram fadados para sempre a sentir falta da metade que lhe fora arrancada. Separadas as partes, cada uma delas colocou-se a procurar a outra. Morriam de fome e inanição, pois cindidas não queriam fazer mais nada. $\mathrm{O}$ amor, explica Aristófanes, seria capaz de reestabelecer a unidade, de garantir a completude, fundir os dois corpos, banir a solidão e garantir a felicidade. O amor reside, nesse cenário, no encontro com o outro, com a alma-gêmea, com a cara metade, com a outra metade da laranja, um desejo de "ser unido e fundado no amado! Serem apenas um!” (PLATÃO, 2000, p. 126).

Para Sócrates, essa visão romântica do amor colocada por Platão (2000) na representação de Aristófanes, por quem nutria certo descaso pelo fato de ter debochado de seu mestre, carregava uma ponta de exagero e de ingenuidade. Sócrates, pela boca de Platão (2000), critica a visão poética e ilusória de Aristófanes e pronuncia a sua verdade sobre o amor: o amor vol.13, nº. 04, Rio de Janeiro, 2020. pp. 1739-1759 
é amor por alguma coisa, alguma coisa que se deseja e que lhe faz falta. Amamos o que desejamos e desejamos aquilo que não temos. O desejo se constitui pela falta, pela incompletude e não pela completude. $\mathrm{O}$ amor é desejo e o desejo é falta. E justamente por isso o amor é

um demônio, intermediário entre os homens e os deuses; filho da pobreza - pois desejoso do que falta - e da Riqueza - pois bravo, resoluto, contente... cheio de recursos - tenta possuir o bem e a felicidade por diversos caminhos, que vão de geração carnal à atividade mais elevada do espírito. Ora a dialética ascendente nos eleva do amor dos belos corpos ao das belas almas e depois, finalmente...o da ciência. Desejoso de imortalidade e aspiração do Bem em si, o amor terrestre conduz ao amor celeste (DURAZOI; ROSSEEL, 1996, p. 369).

Além de nos fazer completos, o amor da teoria platônica é um amor que é despertado pela beleza, não apenas da natureza física, mas pelo belo enquanto virtude do comportamento, da alma. Se pode cobiçar aquilo que não se acha belo, diz Platão (2000), mas dificilmente não se amará esta mesma coisa. Nisso o amor permite superar a superficialidade e acessar o verdadeiramente valioso das coisas e das pessoas. Do desejo físico ao paraíso diria Platão. O amor extrai de nós o melhor como amantes. Embora se inicie como atração sexual, permite lançar luzes sobre nós mesmos. Essa é uma dimensão quase espiritual que Platão (2000) empresta ao amor. O amor é um desejo natural de acessar a bondade e a virtude, de estar unido a elas, de cultivá-las.

Pode-se dizer que os gregos descreveram o amor de três diferentes formas. $\mathrm{O}$ amor como paixão, Eros, é um amor doentio, que se constitui pela falta e nunca poderá ser completo. Nesse tipo de amor a felicidade é uma impossibilidade. Na leitura inicial de Sócrates, no "Banquete", essa posição é bem evidente. Uma segunda manifestação do amor é percebida na Philia, na amizade, e se constitui como um afeto para o outro que está presente, que não é ausência, que se estabelece entre iguais. "Philia é uma forma de devoção cuja melhor tradução é 'amoramizade', mas que floresce não apenas entre o que costumamos chamar de 'amigos', como também em todos esses outros tipos de relação em sua melhor forma" (MAY, 2012, p. 81). Aristóteles distinguiu três diferentes espécies de amizades, em número igual às coisas que merecem ser amadas: a amizade por prazer, a amizade por utilidade e a amizade segundo a virtude. Enquanto as duas primeiras são efêmeras e podem ser conquistadas até mesmo pelos homens maus, a amizade como virtude é um atributo dos homens bons, uma amizade de tipo raro. Se nas duas primeiras formas a amizade se esvai quando cessa o prazer e as vantagens delas decorrentes, constituindo-se em amizades de tipo acidental, a amizade (a verdadeira amizade) decorrente da virtude é reservada aos homens bons pelo fato de poderem ser amigos 
pelo que são por si mesmos. Neste cenário, a amizade e a bondade encontram-se na mesma pessoa. Neste sentido, a amizade tem uma conotação ética e é constitutiva de uma relação pública. Tem, por consequência, um significado político, conecta os cidadãos e os faz ter objetivos comuns (ARISTÓTELES, 2002). A lealdade e a virtude que guiam a amizade verdadeira tornam desnecessária a noção de justiça entre os amigos. Por fim, a terceira forma de amor, tal como entendida pelos gregos, encontra-se na Ágape, na Caritas dos romanos, na ideia de solidariedade. É um amor àquele que não se conhece, de quem não se é íntimo, um amor que é dedicado ao outro pela sua condição de humanidade comum.

Obviamente que estas diferentes formas de amar adquiriram ao longo dos tempos outros nomes, novas funções e conceitos, além de terem sido experimentadas concomitantemente, em intensidades diferentes e em relações distintas. Sem olvidar que a experiência afetiva, entendida aqui de modo amplo, é, ao mesmo tempo interpessoal, subjetiva e também social, uma relação e uma possibilidade individual, interessa-nos aqui é compreender como as novas configurações do amor e afeto, iniciadas sobretudo com o protagonismo do indivíduo moderno, permitiram novas narrativas e a formação de novos tipos de relações legítimas constitutivas da própria ideia de família.

A escolha do âmbito das relações familiares para tratar das novas configurações do afeto é proposital, porque é nas relações familiares, de modo amplo, que o amor e o afeto (e a falta de ambos) adquiriram representações bem vivas de suas potencialidades e debilidades. Mudanças na intimidade, na sexualidade, na relação com os filhos e com os sistemas de produção reordenaram a família como instituição social e como espaço simbólico.

A família passou por várias transformações ao longo da história. Das gigantescas famílias que reuniam sob seu signo (e sob um mesmo espaço geográfico) todos aqueles dependentes de um mesmo chefe e líder, incluindo-se entre eles os escravos, até as famílias monoparentais contemporâneas, muitas transformações afetaram a sua estrutura orgânica e funcional, bem como a definição de seu papel na constituição dos sujeitos individuais e das instituições sociais.

Nas civilizações antigas o casamento não se apresentava como uma união afetiva, uma vez que tinha como principal função o nascimento de filhos homens, os quais iriam dar continuidade ao culto da religião doméstica. Fustel de Coulanges (1975, p. 69) assim declara:

O casamento era assim obrigatório. Não tinha por fim o prazer; o seu objeto principal não estava na união de dois seres mutuamente simpatizantes um com o outro e querendo associarem-se para a felicidade e as caseiras da vida. $\mathrm{O}$ efeito 
do casamento, à face da religião e das leis, estaria na união de dois seres do mesmo culto doméstico, fazendo deles nascer um terceiro, apto para ser continuador desse culto.

Os laços afetivos nas instituições familiares não eram vinculados ao amor ou à escolha pessoal, senão uma forma de se perpetuar os dotes, como na Idade Média, a partir do casamento arranjado. $\mathrm{O}$ amor entre cônjuges era, inclusive, um mal a ser evitado. Os casamentos e o sexo servem para a procriação e não para o deleite, a ponto de São Jerônimo afirmar que um homem que está ardentemente apaixonado por sua esposa é um adúltero. (RICHARDS, 1993). O corpo é diabolizado, desvalorizado, fonte de pecado e de luxuria, prisão e veneno da alma. Por isso mesmo a prostituição sempre foi tolerada pela igreja, considerada um mal necessário para manter a sanidade moral e sexual do resto da sociedade.

No que tange a educação dos filhos, nesta mesma época, a família "não podia portanto, alimentar um sentimento existencial profundo entre pais e filhos" (ARIÈS, 1981, 15), o que não significa que os pais não amassem seus filhos. Segundo Ariès (1981, p. 15), os pais "se ocupavam de suas crianças menos por elas mesmas, pelo apego que lhes tinham, do que pela contribuição que essas crianças podiam trazer à obra comum, ao estabelecimento da família. A família era uma realidade moral e social, mais do que sentimental."

Philippe Ariès (1981) fez um extenso trabalho iconográfico em que percorreu a trajetória da família desde a Idade Média até os tempos modernos. O autor aponta para a descoberta da infância (e do sentimento que lhe é particular) como o principal agente de transformação no despertar do sentimento de família. Durante a Idade Média o sentimento de família era desconhecido, pois o que apresentava valor à época era a linhagem que ia além dos laços de sangue, abrangendo a todos os descendentes de um mesmo ancestral, não importando se essas pessoas coabitavam e se tinham intimidade. Nesta perspectiva, a família se restringia ao grupo de pessoas que residiam juntas, às vezes correspondendo a mais de um casal com seus filhos que moravam na mesma residência. A intimidade, tão característica da família moderna, era desconhecida nessa época. Ela não constituía, era um ainda-não. Não tinha seu estatuto, uma ontologia.

Como a Idade Média foi um período muito marcado por valores ligados à religião, era muito comum que as pessoas se dedicassem às vocações religiosas como forma de santificação. O casamento era, nas palavras de Ariès (1981), uma questão de último caso, uma concessão à fraqueza da carne. Somente a partir dos finais do século XVI e início do XVII que passou a ser 
admitida "a possibilidade de santificação fora da vocação religiosa, na prática dos deveres civis" (ARIÈS, 1981, p. 146).

Na Idade Média o pai tinha sobre os filhos e a esposa, segundo Badinter (1985), o direito de vida e de morte, o direito de castigá-los a seu bel prazer, de até mesmo excluí-los da família. Nesse modelo de relações patriarcais, refere Roudinesco (2003), interessa a transmissão do patrimônio e os casamentos arranjados são a tônica das uniões, sem que os desejos e o amor dos futuros cônjuges fossem levados em consideração. Porém, aos poucos, passa-se a considerar a mãe-esposa não uma escrava, mas uma companheira. Como um reflexo do preceito segundo o qual é preciso "amar ao próximo como a si mesmo", ocorreu um freio ao autoritarismo dos pais, instituindo-se o casamento como uma instituição divina.

Essas transformações no seio familiar não tardaram a alcançar também o casamento, como instituto. Até a metade do século XVIII, Badinter (1985) afirma que o amor não era considerado um valor familiar e social, o que não quer dizer que não existisse, mas não ocupava um lugar, nem tinha a importância que adquiriu na Modernidade. A família residia seu tempo e seu posto no silêncio e não portava sentimentos suficientes para fomentar a inspiração de escritores, artistas e poetas.

Devemos atribuir a esse longo silêncio uma significação importante: não se conferia um valor suficiente à família. Da mesma forma, devemos reconhecer a importância do florescimento iconográfico que a partir do século XV, e sobretudo XVI, sucedeu a esse longo período de obscuridade: o nascimento e o desenvolvimento do sentimento de família. Daí em diante, a família não é apenas vivida discretamente, mas é reconhecida como um valor e exaltada por todas as forças da emoção (ARIÈS, 1981, p. 152).

Um marco decisivo para o surgimento de um novo paradigma fundante da família, em termos materiais e simbólicos, está diretamente relacionado ao desenvolvimento industrial (HORKHEIMER, 1983). Transformações ocorridas entre os séculos XVI e XVII marcaram o rompimento com o modelo de família da Idade Média, engendrando o início da família moderna e consequentemente um novo sentimento: o sentimento de família e o sentimento de amor romântico.

A partir da segunda metade do século XVIII, as esposas passaram, lentamente, a ocupar o lugar de companheiras e o casamento o lugar privilegiado da felicidade, da alegria e da ternura. Essa nova família passa a ser considerada, nos dizeres de Badinter (1985, p. 179), "uma unidade sentimental que engloba marido, esposa e filhos. É o nascimento da moderna família nuclear, que constrói pouco a pouco o muro de sua vida privada para se proteger contra toda 
intrusão possível da grande sociedade". O amor, aos poucos, vai ocupando o vácuo deixado pelo cristianismo. No lugar de "Deus é amor", exsurge o "amor é Deus", de modo que ele se torna a religião não declarada do ocidente. Em certa medida, pode se dizer que nas culturas forjadas pelo cristianismo, o amor genuíno se molda a partir de uma imagem do amor divino (MAY, 2012).

Mas isso não quer dizer que o amor tenha se instalado, definitivamente, como um acontecimento ontológico já no início da idade moderna, nem mesmo na filosofia. Depreendese da leitura contratualista e naturalista de Rousseau, por exemplo, que "a mulher é feita especialmente para agradar o homem [...]. Não se trata da lei do amor, concordo; mas é a da natureza anterior ao próprio amor." A diferença natural que é evidente entre eles, marca também suas atribuições morais. Um, por isso, é forte e ativo e outro, fraco e passivo. (ROUSSEAU, 1995, p. 424). Kant (2000) também atribuiu às mulheres uma posição de inferioridade em relação aos homens. Apesar de não negar sua inteligência, em igualdade de condições, insiste de que se trata de uma inteligência bela, tomada de ingenuidade, sem profundidade. Sua autonomia não é plena e por isso seus papeis sociais são essencializados como menores, como passivos. Tais premissas, evidentemente, não permitem que se viva o amor, o poder e o direito em igualdade de condições e como expressão de liberdade e autonomia.

Nem mesmo as revoluções liberais do século XVIII, como a francesa, alterou profundamente a situação do protagonismo masculino. De fato consagraram princípios de liberdade e igualdade, mas influenciadas e direcionadas por um visão masculina e heteronormativa de sociedade. Liberto da religião, o amor ainda estava prisioneiro das formas repressoras de separação e segregação de gênero que somente nas décadas de 60 e 70 do século XX seriam denunciadas de modo mais contundente.

Somente aos poucos, portanto, a intimidade se instala nas relações familiares. Afeta os corpos e aproxima mães de filhos e mulheres de seus próprios corpos, e a sexualidade começa a construir um itinerário separado e independentemente da reprodução. Inicia-se um caminho, trilhado ao longo dos últimos séculos, da sexualidade como possibilidade instalada nos corpos, como algo apartado da biologia que identifica o sexo com a reprodução indispensável à continuidade familiar. Segundo Giddens (1993, p. 11), “a intimidade implica uma total democratização do domínio interpessoal, de uma maneira plenamente compatível com a democracia na esfera pública”.

Para Luhmann (1991), na medida em que a sociedade moderna tornou-se mais complexa, mais individualizada, o amor como paixão, distinto do amor cortês medieval, aparece 
como um código de comunicação simbolicamente generalizado das individualidades. A literatura romancista teria contribuído com a proliferação deste código na medida em que propagava um tipo ideal de relação amorosa e descrevia os comportamentos adequados a serem esperados dos amantes. No século XVII o amor como paixão surge como código distinto daquele amor vinculado a ideia de serviço e de veneração à amada, típico de uma sociedade estratificada. $\mathrm{O}$ amor paixão instala a possibilidade de escolha do parceiro e livra-se, até certo ponto, do controle social externo. Passa a ser uma questão de decisão do amante em amar e ser amado, mas que também envolve um sofrimento involuntário, sem regras e sem controle. Amase por que se ama. $\mathrm{O}$ amor torna-se conquista, excesso, ilimitado, esquizofrênico, e por isso paradoxal. Deseja comunicar a paixão ao amante sem ter como fazê-lo de modo pleno.

Porém, somente a partir do século XVIII, prossegue Luhmann (1991), o amor paixão vai sendo suavizado, civilizado, estabilizado e ganha contornos de um amor romântico que consegue ser mais eficiente na comunicação e garantidor das individualidades a ponto de se constituir numa condição desejável inclusive para o casamento. Nesse momento o amor romântico transforma-se num código generalizado de comunicação das individualidades e da intimidade, distinto dos demais tipos de códigos de comunicação social. O amor é descaracterizado como paixão sem limites e passa a ser regrado e estável como um valor em si mesmo que não precisa de justificação. A partir do século XX, ainda segundo o autor alemão, o amor estaria perdendo a sua capacidade de comunicação de individualidades diferenciadas, pois se tornou condição não apenas para o casamento, como também para a proliferação dos encontros casuais. Esta constatação do amor como modelo contemporâneo para encontros casuais parece-nos exagerada e induz a uma confusão entre desejo puramente sexual ou biológico e amor que não permite uma conceituação segura da infinidade de tipos de relações possíveis entre parceiros eventuais.

A Modernidade funda um império da intimidade e potencializa suas formas de representação. O amor romântico, como uma possibilidade da individualidade livre e autônoma, numa sociedade em que se esvanecem as formas tradicionais de pertença e identidade, transforma-se em um veículo de esperança para a felicidade e para a auto- realização, uma espécie de religião depois da religião, diriam Beck e Beck-Gernsheim (1998). Isto é, o amor como forma de religião terrena, pois o centro da vida hoje está ocupado não mais pela religião, pela luta pela sobrevivência ou pelos papéis tradicionais de gênero, mas pelas exigências de autodesenvolvimento, o que implica novas formas de vida, de amor e de exercício da sexualidade. Nesta religião, entretanto, os próprios amantes assumem a totalidade das regras e 
dos acordos. Nada que é exterior tem a potência de colocar regras e fazer juízos de justiça. Só os amantes e ninguém mais sabem do seu amor.

En la sociedad occidental de los últimos siglos se ha ido fraguando una forma absolutamente dominante de concebir lo humano y de representar los vínculos entre las personas, que denominaré Pensamiento Amoroso: un conjunto articulado de símbolos, nociones y teorías en torno al amor, que permea todos los espacios sociales, también los institucionales, e influye directamente en las prácticas de la gente, estructurando unas relaciones desiguales de género, clase y etnia, y un modo concreto y heterosexual de entender el deseo, la identidad y, en definitiva, el sujeto (ESTEBAN, 2011, p. 23)

O amor romântico inaugura, portanto, uma nova relação com o afeto. Ele é constituído de afeto, de existencialidade no lugar de funcionalidade. Poder escolher o próprio marido, apaixonar-se por ele e sonhar com a felicidade no casamento é uma grande mudança de paradigma que auxilia na elaboração da ideia de autonomia e consciência de si. Isto é,

o surgimento da ideia de amor romântico tem de ser compreendido em relação a vários conjuntos de influencias que afetam as mulheres a partir do final do século XVIII. Um deles foi a criação do lar. Um segundo foi a modificação nas relações entre pais e filhos; um terceiro, o que alguns chamam de "invenção da maternidade". No que dizia respeito à situação das mulheres, todos eles estavam intimamente ligados (GIDDENS,1993, p. 53).

Com a prática de casamento arranjado sendo deixada de lado em nome do amor e de um novo conceito de família como refúgio, a promessa era a de que essa moderna família encontrasse alívio, felicidade e ternura diante de um mundo que começava a se delinear de competitividade e brutalidade. Segundo Christopher Lasch (1991), a criação dos filhos se converteu em algo mais exigente e os laços entre pais e filhos se intensificaram, sendo uma fonte de tensão na família, dada a sobrecarga emocional na relação entre pais e filhos. Ainda de acordo com Lasch (1991), é nas relações com entes queridos e suas figuras de autoridades que a criança tem suas primeiras experiências. "A socialização faz com que o indivíduo queira fazer o que deve fazer e a família é o agente ao qual a sociedade confia essa tarefa complexa e delicada" (LASCH, 1991, p. 26).

Pensando de acordo com Simmel (1998) ou Goode (1959), o amor passou a se destacar com maior relevância desde as primeiras décadas do século XX. Primeiramente, se fixou como centro na reconfiguração histórica da vida privada, desde Ariès, que escolheu a sentimentalização das relações familiares como uma das linhas de força da Modernidade, frisando a importância do romantismo que, florescente no século XIX, concedeu destaque aos 
afetos - entre cônjuges, entre pais e filhos -, legitimando um ideal de família refúgio, íntima e livremente escolhida (COSTA, 2005).

Além das alterações já mencionadas, a Modernidade trouxe consigo um forte apelo à individualidade e a novas formas de viver "plenamente" a sexualidade, o corpo, o trabalho, o casamento, o amor e sobretudo as relações que se estabelecem nesse ínterim. O sentimento amoroso é, assim, um dos pilares da individualização, pois desafiou a instituição, constituindo uma força subversiva e ameaçadora da fundação matrimonial, subordinada aos interesses da reprodução familiar e social.

Anthony Giddens (1993) trabalha essa mudança de paradigma, situando as transformações da intimidade como novas formas de se relacionar com o mundo e com a autonomia. Referindo-se às mudanças ocorridas no laço amoroso, refere que o

[...] lar passou a ser considerado um ambiente distinto, separado do trabalho, e, pelo menos em princípio, converteu-se em um local onde os indivíduos poderiam esperar apoio emocional, em contraste com o caráter instrumental do local de trabalho. Particularmente importantes em relação a sexualidade, as pressões para se constituírem famílias grandes, características virtuais de todas as culturas prémodernas, deram lugar a uma tendência a se limitar de forma rigorosa o tamanho da família. Tal prática, aparentemente uma estatística demográfica inocente, colocou um dedo no gatilho histórico, no que dizia respeito à sexualidade. Pela primeira vez, para uma população maciça de mulheres, a sexualidade se aparta de um círculo crônico de gravidez e parto (GIDDENS, 1993, p. 36-37).

Além das mudanças ocorridas na esfera privada, algumas foram, inclusive, decorrentes dela. Para Foucault (2012), por exemplo, a invenção da sexualidade foi um processo de formação das instituições sociais modernas. Invenção porque daí para frente o sexo adquire um conteúdo próprio que diz do sujeito, enunciando a sua verdade interna. Os estados Modernos, para ele, assim como as organizações modernas dependem do controle meticuloso das populações através do tempo e do espaço. Tal controle foi gerado pelo desenvolvimento de uma anatomia-política do corpo humano - tecnologias de controle corporal que visam ao ajuste, mas também a otimização, das aptidões do corpo (GIDDENS, 1993, p. 31).

Mais e mais transformações do encontro amoroso se fazem presente. Bauman (2001) refere-se às sociedades Modernas e pós-modernas como produtoras de liquidez. Isso significa dizer que o mundo anterior, cheio de verdades absolutas, dogmas consolidados e, por natural, minados de certezas e seguranças, hoje se perdeu. A certeza que vigorava em épocas passadas não se faz presente nesta. A realidade que nos é imposta contribui para que valores, costumes e hábitos estejam em constante mudança onde o novo é efêmero, ou como diria Marx e Engels (s.d., p. 30), "tudo que é sólido desmancha no ar". 
Essa liquidez abrange todas as dimensões do indivíduo. Os relacionamentos são mais virtualizados, portanto menos simbolizados, até mesmo porque as possibilidades são inúmeras. Qualquer um sabe que "estar num relacionamento" significa muita dor de cabeça, mas sobretudo uma incerteza permanente. Você nunca poderá estar plena e verdadeiramente seguro daquilo que faz - ou de ter feito a coisa certa ou no momento preciso" (BAUMAN, 2004, p. 29).

Bauman (2004, p. 35) ainda menciona que “onde há dois não há certeza”, e que hoje vivemos "uma relação de bolso", e o que revela essa analogia é a "encarnação da instantaneidade e da disponibilidade" (BAUMAN, 2004, p. 36). A tirania da intimidade promove a substituição do erotismo pela sexualidade como satisfação individual. Sexo tornase um ato de prazer individual e não uma ação, e a sexualidade é desconectada da ideia de uma construção relacional, feita a dois e compromissada. Nesse sentido muitas formas de relação são constituídas e alimentadas pelo interesse dos parceiros. O consentimento é a única coisa que não permite, nesse tipo de relação, ser questionado.

O fato é que a introdução da ideia de amor e afeto no seio familiar fez com que a família passasse "a desempenhar um papel ainda mais crucial para a constituição de novas narrativas da identidade, por estar na própria origem do eu e por ser aquilo de que ele precisava se libertar" (ILLOUZ, 2011, p. 16). As expectativas hoje são outras e, se há lugar para o amor, há que se admitir que há lugar também para a agressão, para o desamor e para a indiferença. É que esse amor moderno não se pode alcançar sem algumas contrapartidas amargas: decepção, ódio, rancor, amargura, tristeza. O fato de que os pais voltem todas as suas atenções para o filho constitui também uma exigência permanente para a criança. Ou seja, se antes o filho devia aos pais respeito e obediência, hoje a súplica é por amor e, em contrapartida, os pequenos fornecem suporte emocional aos pais em meio ao mundo caótico e conturbado no qual vivem. O filho confronta o pai e a mãe com sua própria história de vida (BECK; BECK-GERNSHEIN, 1998).

Mas se o amor moderno é um sentimento que se fundamenta em si mesmo, ou seja, somente nos sujeitos que o vivenciam, então talvez "el no amar no es una infracción de las leyes, no es un acto criminal, aunque con ello se hiera la vida de otros más profundamente que con un robó o una lesión" (BECK; BECK-GERNSHEIM, 1998, p. 302). Logo, quem sacrifica o matrimônio, a família, a paternidade e, ao fim e ao cabo, o bem-estar "dos seus", talvez não esteja cometendo crime ou pecado, pois está cumprindo a lei da autorrealização, mandamento primeiro da sociedade moderna. "El amor no se puede forzar", dirão Beck e Beck-Gernsheim (1998, p. 302). 
Então, em decorrência desses novos rearranjos e dessas novas possibilidades do encontro, a partir de 1960 a família tem como particularidade dois indivíduos que se juntam através de uma durabilidade relativa em busca de relações íntimas ou realização sexual, de modo que a transmissão da autoridade vai se tornando mais difícil e questionada à medida que os divórcios, a fragmentação e as reorganizações conjugais aumentam, no qual a família não é mais garantida pela presença indesatável do divino através da convenção do casamento, tornando-se cada vez mais um acordo livre e outorgado entre os indivíduos enquanto o amor resistir (ROUDISNESCO, 2003).

\section{OS DESAFIOS DO DIREITO EM NORMATIZAR E "NORMALIZAR" AS NARRATIVAS AFETIVAS, AMOROSAS E FAMILIARES}

Por mais que a Modernidade tenha inaugurado um novo estado de coisas no campo político e jurídico que melhorou as condições de sociabilidade do mundo ocidental, é também verdadeiro que este mesmo período não atendeu às exigências de acesso à complexidade. A sua potência igualizadora e homogeneizadora consagrou narrativas racionalistas e instituições totalizantes, reduzindo o plural, as formas autênticas marcadas pela diferença. A igualdade abstrata é a grande chave para acessar a modernidade jurídica.

Com o direito não foi diferente. Sua expressão moderna normatizou a normalidade e criminalizou a "anormalidade" (FOUCAULT, 2014). No contexto de governamentalidade neoliberal o direito reduziu sua carga de interdições e repressões, e passou a controlar pela definição das subjetividades normais e anormais que pretende normalizar. No campo da regulação sexual e de tudo o que ele envolve, a normalidade visada pelo direito, signatário dos valores do seu tempo, era a manutenção das uniões familiares de tipo heterossexual e com finalidade reprodutiva. Havia uma sexualidade e um tipo de desejo tido com impróprio e, portanto, alvo de denúncia e expurgo pelos sistemas sociais. A família tinha um estatuto definido e sua forma de representação um conteúdo claro, uma sexualidade clara, funções claras, sujeitos com papéis definidos. Um tipo de direito de amar que portava vantagens apenas ao homem, ao marido (RODOTÀ, 2015).

As ondas liberalizantes, o afrouxamento religioso e moral e a hiperindividualização da vida colocaram o direito numa nova direção. Hoje, o direito normaliza a descontinuidade dos casamentos, a possibilidade da ruptura permanente. Normaliza os diversos tipos de encontros amorosos que tornam a regulação por oposição uma alternativa obsoleta. Não tem sentido 
regular, no caso amoroso, quando praticamente tudo é possível. Não tem sentido a norma reprimir quando não existem, no campo do desejo, ilícitos e anormalidades a serem "combatidos" e evitados.

O amor romântico, em sua origem, é uma espécie de conspiração contra a sociedade. Não conhece limites. Nem os limites dos estamentos e das classes, nem os limites da lei e da moral (BECK; BECK-GERNSHEIN, 1998). Aos poucos ele é aprisionado como um projeto e passa a fazer eco das normas e da própria comunidade. Sendo o amor romântico uma utopia da felicidade individual, transforma-se num projeto totalizante e por isso numa impossibilidade. Ele perde sua capacidade de gerar segurança e é facilmente dissolvido na paternidade, sexo, erotismo, convivência, flertes, relação amorosa, união familiar etc. Beck e Beck-Gernsheim (1998) chegam a falar da morte do amor, de sua incapacidade de comunicar para além dos próprios sujeitos da relação. Atualmente, com a liberalização da vida pelo afrouxamento das barreiras estamentais e familiares, o amor perde sua capacidade de comunicar e estabelecer laços duradouros, mas abre-se como possibilidade, como aventura, como projeto de hipóteses imprevisíveis.

Desse modo, ainda com Beck e Beck-Gernsheim (1998), com a liberação da moral e do direito, o amor se converte num assunto exclusivo dos indivíduos que se amam, num modelo de salvação individual que se prometem sujeitos isolados. É uma resposta contra a individualização, uma aposta na formação de um sentido de pertença a dois. Por isso a individualização da vida ter produzido o ideal de matrimônio por amor.

O amor se justifica de modo individual e emocional e não de modo tradicional. Só os amantes podem falar do seu amor. São titulares daquilo que sentem e os únicos que dispõem da verdade e do direito de seu amor. Por isso estabelecem papeis entre si, como atores que devem representar um personagem prefigurado. $\mathrm{O}$ direito externo não possui alcance sobre eles, os quais são os únicos a fazerem a justiça e justificarem-se. "El amor no se puede reclamar ante los tribunales, no hay posibilidad de revisión. El amor y la justicia son palabras que pertenecen a idiomas totalmente distintos" (BECK; BECK-GERNSHEIM, 1998, p. 340-341).

$\mathrm{O}$ amor se auto fundamenta, apresentando-se como um local de segurança para os amantes. Numa sociedade líquida, transforma-se numa espécie de refúgio. Mas é, por outro lado, uma fórmula vazia que exige uma complementação geralmente alcançada pelo consenso daqueles que amam. Apresenta-se diverso, distinto, em se tratando dos conteúdos que lhe dão sentido. Por isso, o consenso é a única coisa que está aberta para a validação pública, não os conteúdos acordados. Nesse sentido o direito estatal reduz a sua capacidade de intervenção 
substancial, limitando-se a garantir a legitimidade dos procedimentos de acordos. O direito é chamado apenas para reestabelecer as regras do jogo democrático a dois (BECK; BECKGERNSHEIM, 1998).

Esse movimento de liberalização regulatória desempenhou um papel simbólico e institucional importante, especialmente no tocante ao reconhecimento de famílias até então desprezadas pelo direito. O casamento homossexual e outras formas de união ganharam sentido e proteção justamente por conta da proibição de se regular os corpos e o amor. A proteção jurídica, nesse caso, é o resultado de um evento paradoxal: justamente por não poder regular mais o amor, o sexo, é que a liberdade dos amantes se tornou condição para todo e qualquer tipo de proteção. A proteção dos homossexuais está mais centrada na impossibilidade de se regular, na liberdade dos sujeitos, no que na possibilidade de se regular. A proteção jurídica lhes dá garantias objetivas e um reconhecimento inegavelmente importante, mas é na condição de amor libertado do direito que as uniões se fundem e ganham vida.

Libertado do direito, os sujeitos, contudo, não libertaram o amor, no sentido de construir novas concepções sobre ele. É interessante notar que a liberdade sexual não fundou um amor livre. A busca pelo amor, pela pessoa certa, parece ser o objetivo de todas as relações afetivas. Como efeito de um eu narcísico-depressivo típico da sociedade ocidental, o outro é (ou deveria ser) mero prolongamento do eu, de modo que nas relações afetivas também as expectativas giram em torno de um amor, no mínimo, agradável, em meio ao que Han (2014, p. 11) denomina de um "inferno do igual".

Nessa utopia do amor sem limites, da possibilidade do amor com esperança pessoal, o direito, quando requisitado, continua declaradamente "avançando o sinal". Parece que a liberdade do amor incomoda o direito, e um avanço estrutural e epistemológico é notório quanto o tema é o amor, o afeto, pois o direito e os Tribunais, geralmente, têm dito mais do que poderiam dizer. Juridicizou o que não era possível fazê-lo. Streck (2012) tem apontado, com propriedade, sobre a indevida e excessiva utilização dos princípios como forma de o direito colonizar aquilo que lhe é estranho. Denuncia a confusão, tão difundida na teoria e prática jurídicas nacionais, entre valores e direito, entre afetos e direito, entre política e direito, como se tudo pudesse, de alguma forma, apresentar-se no direito sob a roupagem de princípios.

Tornou-se comum, por exemplo, a utilização da afetividade como princípio do direito de família, a ponto de um grande número de decisões judiciais e a doutrina dedicada ao tema terem reservado um capítulo especial sobre o assunto. É igualmente habitual a defesa da 
afetividade como uma categoria jurídica capaz de instituir e destituir tutelas e garantias jurídicas.

É evidente o exagero. Sentimento pode ser direito? Qual o limite para essa eleição? Quais os sentimentos merecem proteção? Quem escolhe esses sentimentos? A doutrina, os Tribunais? Ora, pode-se até querer (e isso querem os mais variados sistemas sociais) que as famílias se constituam e preservem seus laços afetivos da melhor forma possível, mas o afeto como tal não é algo que possa ser codificado pelo sistema jurídico como uma condição de possibilidade de um direito. Da mesma forma que se fala do amor, a afetividade é encruada na relação subjetiva que invariavelmente não requer elementos externos de confirmação. São os envolvidos na relação afetiva os únicos donos e juízes de seu afeto. Ao colocar a noção de afetividade como contraposta a de parentalidade biológica, os Tribunais indicam uma preferência pelas escolhas dos indivíduos, pelos seus acordos, pela segurança que o afeto representa numa sociedade em que os laços forjados pela tradição diminuíram. O problema é que o afeto, tal qual o amor, ao ser transformado pelo direito em norma ou princípio, passa a indicar uma posição de correto e de necessário, de obrigação, impondo sanções no caso de afetos não correspondidos. Certamente aqui estamos, como dito antes, diante de um excesso e o direito passa a dizer mais do que poderia e consegue dizer.

É legitimo que um pai ou um filho queiram o amor um do outro até o fim de seus dias, mas certamente não será o direito que garantirá que isso aconteça. Do amante, do pai, do filho, da mãe, daqueles que esperamos amor, só nos resta uma correspondência, uma palavra que se torne ato e acolhimento, um beijo que não seja por obrigação e um cuidado que não esteja codificado na lei. Relações psicanalíticas de toda ordem conformam uma relação de afeto. Pais amam filhos que não os amam (e vice-versa) por diversas razões. Sujeitos amam de modo diferente por conta de sua historicidade. Se é possível falar num amor e num afeto por obrigação, é plausível que se exija do direito que conceitue um afeto adequado, um bom afeto, um afeto que o direito considere suficiente. Ou como saberemos estar amando de modo adequado juridicamente? Os pais e as famílias deixam de existir quando não amam na medida em que se espera deles?

Definitivamente não se poder normatizar o desejo e o amor. O direito, ao menos nas suas facetas mais liberalizantes, já não pode dizer mais nada sobre licitudes e ilicitudes do amor, que se abre como possibilidade, como substância e existencialidade do sujeito enquanto tal e apenas isso. Justamente ao libertar-se do direito e de seus códigos castradores é que o amor tornou-se livre e capaz de ser plenamente o que é. O amor não necessita de legitimação jurídica, vol.13, no. 04, Rio de Janeiro, 2020. pp. 1739-1759 1755 
mas, paradoxalmente, quer tornar-se direito para realizar-se plenamente. O direito ao amor é um apelo a não intervenção, a não expropriação, a não castração, a possibilidade de libertação que encontra seu amparo no desejo que institui democraticamente e autonomamente cada sujeito. No lugar das subjetividades construídas pelo saber dominante, que destrói o sujeito, aposta-se na autenticidade de cada um como elemento emancipatório que plenifica a ideia de liberdade em condições de paridade entre os diversos sujeitos. Definitivamente, o "amor, como a democracia, demanda sempre a presença de um sentido inesperado". (WARAT, 2004, p. 318).

\section{CONSIDERAÇÕES FINAIS}

No momento em que o direito libertou o amor de seus códigos de licitude e de ilicitude, de sua dimensão castradora e reguladora, é que sua potência mais intensa se tornou possível. O direito pleno ao amor surge quando o próprio amor se liberta dos sistemas de regulação social tradicionais e se instala como direito de pura liberdade, como um acontecimento autêntico.

Apesar de o direito e os tribunais propagarem uma função constitutiva normativa da dimensão afetiva, é evidente que o amor ou a falta dele é um assunto exclusivo daqueles que amam e o direito, por melhores intenções que tenha, não é capaz de acessar o seu estatuto. As novas famílias, as novas formas de amar, resultam da defesa da democracia como lugar da autonomia, como espaço simbólico e histórico de manifestação das diferenças que constituem o desejo de cada sujeito. Amar é um direito, mas um direito de se amar a seu modo e não ao modo de um direito que impõe restrições e obrigações, como de regra sempre fora o direito balizado por padrões heteronormativos.

O amor como experiência plena é fundamental para a construção de espaços democráticos que dependem da autenticidade, da alteridade e do reconhecimento da diferença do outro. Tem um apelo ético, uma carga de sentido nunca completa que se alimenta da constante incerteza e insegurança que funda os desejos e os interesses de cada cidadão. Nessa direção, o amor, em seus diversos formatos e modos de representar, é importante para a justiça, para a formatação de uma sociedade de acontecimentos livres, autônomos e em igualdade de condições. Trata-se de uma função pública do amor, da possibilidade de ele conduzir todos os tipos de narrativas, de desejos, de gozos, de entendimentos compartilhados e abertamente vividos por todos os sujeitos como um direito de verdade. Se o amor é importante para a construção dos destinos e para a qualidade moral de cada ser individualmente, seguramente vai influenciar na reforma estrutural e na formação dos novos arranjos familiares. Cada pessoa 
individualmente considerada é a unidade da distribuição política e os direitos em igualdade de condições são a condição de possibilidade para que cada sujeito se realize como um projeto independente (NUSSBAUM, 2002). Por isso, entendemos que o STF decidiu adequadamente quando reconheceu o mesmo direito das uniões heterossexuais para as uniões entre pessoas do mesmo sexo, pois potencializou a vida, a liberdade, a autonomia, valores e direitos fundamentais importantes em qualquer democracia.

O direito pode impor o dever de cuidado, de zelo, respeito e proteção. Isso, além de desejável em qualquer relação, pode ser cobrado de quem quer que seja. É uma ação objetiva que se pode determinar, inclusive de modo financeiro. Contudo, não se pode cobrar amor de quem não tem para dar, simplesmente, pois amar não é uma obrigação, amar não é um acontecimento objetivo que possa ser encapsulado e exigido de modo material. Do mesmo modo não se pode fulminar o desejo e o amor de quem o possui. Assim como não se pode obrigar alguém a apaixonar-se, o direito é incapaz de impedir que alguém ame ou deixe de amar. Os novos nomes do amor se abrem como possibilidade e como liberdade. O Amor é, definitivamente, um evento a dois, uma democracia a dois. Exige um itinerário seu, sem restrições, proibições, imposições e obrigações. Afinal, como diz Caetano Veloso, em sua música Paula e Bebeto, "qualquer maneira de amor vale a pena, qualquer maneira de amor vale amar".

\section{REFERÊNCIAS}

ARISTÓTELES. Ética a Nicômaco. São Paulo: Martin Claret, 2002.

ARIÈS, Philippe. História Social da Criança e da Família. Rio de Janeiro: Livros Técnicos e Científicos, 1981.

BAUMAN, Zygmunt. Modernidade Líquida. Rio de Janeiro: Jorge Zahar, 2001.

BAUMAN, Zygmunt. Amor Líquido. Rio de Janeiro: Jorge Zahar, 2004.

BECK, Ulrich; BECK-GERNSHEIN, Elisabeth. El normal caos del amor: las nuevas formas de la relación amorosa. Barcelona: Ediciones Paidos Ibérica, 2001.

BADINTER, Elisabeth. Um Amor Conquistado: O Mito do Amor Materno. Rio de Janeiro: Nova Fronteira, 1985.

COULANGES, Fustel de. A cidade antiga. 12. Ed. São Paulo: Hemus, 1975. 
COSTA, Sergio. Amores fáceis: romantismo e consumo na modernidade tardia. Novos Estudos, 2005, v. 73 p.111-124.

DIAS, Maria Berenice. Manual de Direito das Famílias. 3. ed. rev., atual. e ampl. São Paulo: Revista dos Tribunais, 2006.

DURAZOI, Gerard; ROUSSEL, André. Dicionário de Filosofia. 2. ed. Campinas - SP: Papirus Editora, 1996.

ESTEBAN, Mari Luz. Crítica del pensiento amoroso: temas contemporáneos. Barcelona: Bellaterra, 2011.

FOUCAULT, Michel. História da sexualidade I: a vontade de saber. Rio de Janeiro: Ed. Graal, 2012. 2014. Os anormais: curso no Collège de France. São Paulo: Ed. WMF Martins Fontes,

GIDDENS, Anthony. As transformações da intimidade: sexualidade, amor e erotismo nas sociedades modernas. São Paulo: Editora da Universidade Estadual Paulista, 1993.

GOODE, Willian J. The theoretical importance of love. American Sociological Review, 24: 38-47, 1959.

HAN, Byung-Chul. A agonia de Eros. Lisboa: Relógio D’Água Ed., 2014.

HORKHEIMER, Max. Autoridade e Família. Lisboa: Apaginastantas, 1983.

ILLOUZ, Eva. O amor nos tempos do capitalismo. Tradução de Vera Ribeiro. Rio de Janeiro: Zahar, 2011.

2016.

Por qué duele el amor? Una explicación sociológica. Buenos Aires: Katz Editores,

KANT, Immanuel. Observações sobre o belo e o sublime. Campinas: Papirus, 2000.

LASCH, Christopher. Refúgio num Mundo sem Coração: A Família: Santuário ou Instituição sitiada? Rio de Janeiro: Paz e Terra, 1991.

LUCAS, Doglas Cesar; GHISLENI, Pâmela Copetti. O amor e o direito pertencem a "idiomas" distintos: uma crítica à juridicização do afeto. RBSD - Revista Brasileira de Sociologia do Direito, v. 4, n. 3, p. 106-131, set./dez. 2017. Disponível em: <http://revista.abrasd.com.br/ojs/index.php/rbsd/article/view/155/127>. Acesso em: 07 set. 2017.

LUHMANN, Niklas. O amor como paixão: para a codificação da intimidade. Lisboa, Difel, 1991. 
MAY, Simon. Amor: uma história. Tradução de Maria Luiza X. de A. Borges. Rio de Janeiro: Jorge Zahar Ed., 2012.

NUSSBAUM, Martha. Emociones políticas. Por que el amor es importante para la justicia? Barcelona: Paidós, 2014.

Las mujeres y el desarrolho humano. Barcelona: Herder, 2002.

RICHARDS, Jeffrey. Sexo desvio e danação. Rio de Janeiro: Jorge Zahar, 1993

RODOTÀ, Stefano. Diritto d'amore. Bari: Laterza, 2015.

ROUDINESCO, Elisabeth. A família em desordem. Rio de Janeiro: Jorge Zahar, 2003.

ROUSSEAU, Jean-Jacques. Emilio: ou, Da Educação. Tradução de Sérgio Milliet. 3. ed. Rio de Janeiro: Bertrand Brasil, 1995.

SIMMEL, Georg. On the sociology of the family. Theory, Culture and Society, 15 (3-4): 283-293, 1998[1895].

STRECK, Lenio Luiz. Verdade e consenso: constituição, hermenêutica e teorias discursivas. São Paulo: Saraiva, 2011.

Do pamprincipiologismo à concepção hipossuficiente de princípio: dilemas da crise do direito. Revista de Informação Legislativa, a. 24, n. 194, abr./jun. 2012, p. 07-21.

Disponível em:

<https://www2.senado.leg.br/bdsf/bitstream/handle/id/496574/000952675.pdf?sequence=1>. Acesso em: 23 jan. 2017.

WARAT, Luis Alberto. O amor tomado pelo amor. Crônica de uma paixão desmedida. In: Territórios desconhecidos. V.1. Florianópolis: Fundação Boiteux, 2004.

Trabalho recebido em 27 de fevereiro de 2019

Aceito em 14 de junho de 2020 